原 著

順天堂医学 $43(2)$

p. 280 292 (1997)

\title{
小児のC型慢性肝炎に対するインターフェロン 治療効果の臨床病理学的検討
}

\author{
A clinicopathological study of efficacy of interferon \\ therapy in children with chronic hepatitis $\mathrm{C}$
}

\author{
尾上昌 弘*1)2) \\ MASAHIRO ONOUE, M.D.
}

目的：小児のC型慢性肝炎に対するインターフェロン（IFN）治療効果の予測因子および長期 予後を臨床病理学的に検討する.

対象と方法：天然型の IFN- $\alpha$ （24週間；計 800 万単位 $/ \mathrm{kg}$ ）を投与し, その効果が判定可能 なC型慢性肝炎患児26例を対象とした.

IFN 治療効果は, 投与終了後 6 カ月以内に血清トランスアミナーゼ (ALT) 值が正常化し以 後も 6 カ月にわたり正常, かつ持続的に血清 HCV-RNA 除性例を著効 (CR 群12例), それ以 外を非著効 (NCR群14例) と判定した.

肝針生検はIFN療法を開始前 6 力月以内（全例）および, 終了後 2 年 $(9 / 26$ 例）で行った. 生検所見をヨーロッパ分類および, Modified Histology Activity Index（Modified HAI）スコ アで評価し，胆管障害・リンパろ胞形成・好酸体壊死・脂肪変性，および鉄沈着も検索した。

結果：肝生検所見 (IFN 治療前) をIFN 治療効果別に比較すると, (1)ヨーロッパ分類上の各組 織型は両群間で有意差がなかった. (2)Modified HAI スコアは, 壊死炎症反応, 線維化および Total のいずれも両群間で有意差がなかった. (3)胆管障害・好酸体壊死および脂肪変性は NCR 群に，またリンパろ胞形成は CR 群に高率にみられたが，いずれも両群間で有意差がなかった. 一方，鉄沈着は NCR 群 $(57 \%)$ が CR群 $(8 \%)$ と比較して有意に高率にみられた $(\mathrm{p}=0.009)$. これら 5 項目の組織所見のうち 3 項目以上を保有する症例およびリンパろ胞形成を除いた 4 項目 中 2 項目以上を保有する症例は，CR群 vs. NCR 群でそれぞれ0\% vs. $36 \% \cdot 8 \%$ vs. $71 \%$ と $\mathrm{NCR}$ 群に有意に高率にみられた $(\mathrm{p}=0.021 ・ 0.001)$.

IFN 治療前後で肝生検所見を比較し得た 9 例（CR 7 例・NCR 2 例）のうち 8 例（CR 7 例 • NCR 1 例) で組織進行度が改善していたが正常化例はなかった。

結論：小児のC型慢性肝炎に対するIFN 治療効果は, 病理組織学的に鉄沈着と組織所見の保有項 目数により予測可能であり, 著効例での組織学的改善には治療終了後 2 年以上の期間が必要である.

キーワード：小児，C型慢性肝炎，インターフェロン，肝組織所見

Key words: children, chronic hepatitis $\mathrm{C}$, interferon, liver histology

* 1 ) 順天堂大学医学部病理学第一講座

* 2 ）自衛隊中央病院小児科

* 1 ) Department of Pathology ( I), Juntendo University School of Medicine, Tokyo, Japan

* 2 ) Department of Pediatrics, Self Defense Forces Central Hospital, Tokyo, Japan

[Oct. 4, 1996 原稿受領〕（Nov. 28, 1996 掲載決定） 


\section{緒言}

C型慢性肝炎は，成人では自然治癒がほとんど 期待できず緩徐ではあるが確実に進行し，感染か ら20～30年の経過で肝硬変さらに肝癌に至る1）2). このためインターフェロン(以下IFNと略) 療法が 導入されたが，その著効率は20〜30\%である3） 4). IFN 効果を規定する因子としてC 型肝炎ウイルス (以下HCV と略)の遺伝子型 (genotype) ・血清 $\mathrm{HCV}-\mathrm{RNA}$ 量，あるいは肝組織進行度などが報 告されている5) 10).

一方，小児のC型慢性肝炎は成人例と比較し て，(1)自然治癒症例がある（約10\%）11）12)，(2)基 礎疾患に血液・悪性腫瘍があり, 免疫抑制剂投与 歴や頻回の輸血歴を有する症例が多い11) 13), (3) 基礎疾患や治療歴の相違により組織学的進行度が 異なるものの11１4）15), 進展例が少ない11１5）16), (4) IFN 療法の著効率は 40 50\%程度 ${ }^{17) ~ ~ 22) ~}$ と高 く, 副作用も軽(17) 22), などの特徵がある. し かし, 小児例では IFN 療法の効果予測因子とし て, 臨床的には血清 HCV-RNA量 ${ }^{20)}$ が, 病理組 織学的には鉄沈着18) が重視されているのみで, いまだ十分に検討されていない.

そこで筆者は，小児のC型慢性肝炎に対する IFN 療法の効果予測因子を明らかにする目的で 主に治療前の肝生検所見を, また追跡肝生検が可 能であった例ではIFN療法前後での組織所見を詳 細に検討した。

\section{対象と方法}

\section{1. 対象}

1990年10月から1995年 8 月の約 5 年間に IFN 療法を開始した小児 C 型慢性肝炎 30 例のうち, 肝 生検未実施 (血友病) 1 例 - IFN 治療期間不足 (脱落例) 1 例・IFN 治療効果の判定期間不足 2 例の計 4 例を除いた26例を対象とした. 対象例は 全例とも肝生検前 6 力月以上にわたり血清トラン スアミナーゼが高值 (ALT 值 > 30IU / ml) で, HCV 抗体および血清 HCV-RNA も陽性で, 病理
組織学的にも慢性肝炎であった。 また,これらは B型肝炎, サイトメガロ, Epstein-Barr などの ウイルス感染がなく, ウイルソン病などの代謝疾 患, あるいは自己免疫性肝炎にも罹患していない。

対象児はいずれも初診時16歳未満の小児であ り, 男児18例・女览 8 例であった. IFN療法の開 始時年齢は 5 〜 19歳 (平均 9.8歳) であった。基 礎疾患として血液・悪性腫瘍が19例あり（以下 A 群と略), 内訳は急性白血病が15例, 重症再生不 良性貧血・神経芽細胞腫・肝芽腫および血球貪食 症候群がそれぞれ 1 例であった。これらはいずれ も, 不特定多数のドナーから頻回に輸血され, 抗 癌剂などの免疫抑制剂も投与されていた，A 群を 除いた残りの 7 例 (以下 B 群と略) は, 先天性心 疾患 5 例 - 溶血性尿毒症症候群 -なし（母児感染 疑い）がそれぞれ 1 例であった. 輸血例は 6 例 (複数回 1 例 1 回 5 例) で, 散発例 (母児感染疑 い例）が 1 例であった（表-1）。

HCV 感染時期は血清トランスアミナーゼ值の 変動から正確に決定するのは困難であったが, 大 部分の症例が基礎疾患の寛解導入時の 1 力月以内 に輸血されており，この時期を HCV 推定感染時 （年齢）とした。なお輸血は日本赤十字血液七ン ターが第二世代の HCV 抗体による献血スクリー ニングを開始する1992年以前に行われた.

\section{IFN療法}

天然型 IFN - $\alpha$ (住友製薬あるいは大塚製薬) の 10 万単位 $/ \mathrm{kg} /$ 日（最大 600 万単位）を連日 2 週間, その後, 週 3 回 22 週間投与した（総投与量 800 万単位 $/ \mathrm{kg}$ ).

効果判定は, IFN投与を終了後 6 力月以内に血 清トランスアミナーゼ值が正常化し, それ以降も 6 カ月にわたり正常で，かつ持続的に血清 HCVRNAが陰性であったものを著効 (以下 complete response : CR と略), それ以外を非著効 (以下 non-CR : NCR と略) とした.

\section{3 . 肝の病理組織学的検索}

肝生検は患児あるいは患家に書面で同意を得た 後に, $18 \mathrm{G}$ のュアーカット針 (TSK Laboratory ；Japan）を用いて経皮的に肝組織を採取した。 
表 -1 患児背景

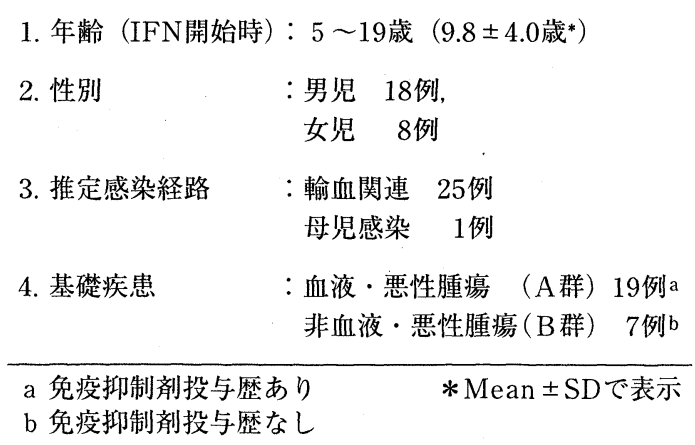

検体はホルマリン固定, 脱水およびパラフィン包 埋し, 約 $3 \mu \mathrm{m}$ の薄切切片を作成後, Hematoxylin-Eosin (HE), Azan-Mallory, Periodic Acid-Schiff (PAS), ジアスターゼ消化-PAS (D-PAS)，鍍銀，および鉄 (Perls' Prussian Blue ) の 6 種類の染色を施した.

$\mathrm{A}$ 群では基礎疾患の治療終了後 2 年以上を経過 した時点で肝生検を実施し, 生検後 6 力月以内に IFN療法を開始した. 推定感染時から肝生検時ま では平均 6 年であった. また， 9 例ではIFN療法 の終了後 2 年を経過した時点で追跡肝生検を施行 した。

肝生検所見は, ヨーロッパ分類 ${ }^{23)}$, および Schvarczら 24)によって modifyされたKnodell ら25)の Histology Activity Index (以下 Modified HAI と略，表-2）スコアを用いて組織進行度を評価 した. Modified HAI スコアはカテゴリーI〜II のスコアを合計した壊死炎症反応スコア，カテゴ リーIVの線維化スコア, およびカテゴリー I 〜 IV のスコアを合計したTotal スコアの 3 種類で表示 した.

さらに，胆管障害・リンパろ胞形成・好酸体壊 死・脂肪変性, および鉄沈着の 5 項目について, それぞれの重症度を grading した（表-3）。すな わち，いずれの項目とも所見なしを Grade 0 と し，リンパろ胞形成については明らかな胚中心が ないが境界明暸なりンパ球の集簇, あるいはろ胞
形成をGrade 1, 胚中心をもつリンパろ胞形成を Grade 2 とした。 その他の 4 項目は門脈域あるい は小葉内での分布程度により Grade 1, 2 とした. なお，胆管障害はリンパ球浸潤・上皮の重層化・ 核の濃縮・細胞質の空胞化や好酸性変化とした。

\section{4. ウイルス学的検索}

第二世代の HCV 抗体は, Abbott HCV EIA 2 nd Generation にて測定した. HCV 遺伝子型 (genotype) は，コア領域の型特異的プライマー を用いたRT nested-PCR 法 (Okamoto ら ${ }^{26)}$ ) により決定した. 血清HCV-RNAの定性は 5’末 端非翻訳領域にプライマーを置いた RT nestedPCR法 ${ }^{27)}$ により, 血清HCV-RNAの定量はmulticyclic RT-PCR法（Ishiyama ら ${ }^{28)}$ ) により現血清 あるいはー $70^{\circ} \mathrm{C}$ の保存血清を用いて測定した。な お, RT nested-PCR 法の HCV-RNA 検出限界

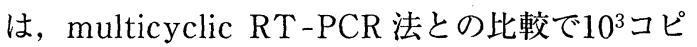
一 /mlであった. IFN 治療開始前の血清 $\mathrm{HCV}$ RNA 量は, 3 カ月以内の検体を用いた。

\section{5 . 統計処理}

測定值は平均值士標準偏差で表示し，測定值に は $\mathrm{t}$ 検定を, 比率にはカイ二乗検定を用いて，危 険率が $0.05 〜 0.1$ 有意ではないが傾向ありとし 0.05未満を有意とした。

\section{結果}

1. IFN 治療効果別の臨床所見 (IFN 治療前) の 比較

対象26例のうち，CR が12例 $(46 \%) \cdot \mathrm{NCR}$ が 14例 (54\%) であり，基礎疾患別の CR 率は， A 群で32\% (6/19例) ・ B群で86\% (6/7例) で あった. CR 群とNCR群との間でIFN治療前の臨 床所見を比較すると（表-4）, CR群はA群例お よび HCV genotype II 型例がそれぞれに有意に 少なく $(p=0.014,0.033)$, 血清HCV-RNA量が 有意に低值であり $(p=0.041)$ ，血清ALT 值が有 意に高かった $(\mathrm{p}=0.008)$.

2. IFN治療効果別の肝生検所見 (IFN治療前) の比較 
表-2 Modified Knodell HAI スコア

(Schvarcz ら, 1991)

\begin{tabular}{|c|c|c|c|c|}
\hline 点数 & $\begin{array}{c}\text { I } \\
\text { 削り取り壊死 } \\
+/ \text {-架橋壊死 }\end{array}$ & $\begin{array}{l}\text { II } \\
\text { 小葉内の変性 } \\
\text { 壊死 }\end{array}$ & $\begin{array}{c}\text { III } \\
\text { 門脈域の炎症 }\end{array}$ & $\underset{\text { 線維化 }}{\mathrm{IV}}$ \\
\hline 0 & None & None & None & None \\
\hline 1 & $\begin{array}{l}\text { Mild PMN } \\
\qquad(<10 \%)\end{array}$ & $\begin{array}{l}\text { Mild } \\
(<1 / 3 \text { of lobules } \\
\text { or nodules })\end{array}$ & $\begin{array}{l}\text { Mild } \\
(<1 / 3 \text { of portal } \\
\text { tracts })\end{array}$ & $\begin{array}{l}\text { Fibrous portal } \\
\text { expansion }\end{array}$ \\
\hline 2 & $\begin{array}{l}\text { Mild to Moderate } \\
\quad(10 \sim 25 \%)\end{array}$ & & $\begin{array}{l}\text { Mild to moderate } \\
\text { increase of infla- } \\
\text { mmatory cells }\end{array}$ & $\begin{array}{l}\text { Fibrous portal } \\
\text { expansion with } \\
\text { incomplete septa }\end{array}$ \\
\hline 3 & $\begin{array}{l}\text { Moderate PMN } \\
\quad(25 \sim 50 \%)\end{array}$ & $\begin{array}{l}\text { Moderate }(1 / 3 \sim 2 / 3 \text { of } \\
\text { lobules or nodules })\end{array}$ & $\begin{array}{l}\text { Moderate }(1 / 3 \text { to } \\
3 / 2 \text { of portal tracts })\end{array}$ & $\begin{array}{l}\text { Bridging fibrosis } \\
(\mathrm{P}-\mathrm{P} / \mathrm{C}-\mathrm{P})\end{array}$ \\
\hline 4 & $\begin{array}{l}\text { Marked PMN } \\
\quad(>50 \%)\end{array}$ & $\begin{array}{l}\text { Marked }(>2 / 3 \text { of } \\
\text { lobules or nodules })\end{array}$ & $\begin{array}{l}\text { Marked } \\
(>2 / 3 \text { of portal tracts })\end{array}$ & Cirrhosis \\
\hline 5 & Moderate $\mathrm{PMN}+\mathrm{BN}$ & & & \\
\hline 6 & Marked PMN+BN & & & \\
\hline 10 & Multilobular necrosis & & & \\
\hline
\end{tabular}

表 -3 組織所見の grading

\begin{tabular}{lcll}
\hline \multicolumn{1}{c}{ Grade } & 0 & \multicolumn{1}{c}{1} & \multicolumn{1}{c}{2} \\
\hline 胆管障害 & None & $<1 / 3$ of portal tracts & $\geqq 1 / 3$ of portal tracts \\
リンパろ胞形成 & None & $\begin{array}{l}\text { definite aggregation or follicles } \\
\text { without germinal centers }\end{array}$ & $\begin{array}{l}\text { lymphoid follicles with } \\
\text { germinal centers }\end{array}$ \\
好酸体壊死 & None & present in some of lobules & present in all of lobules \\
脂肪変性 & None & $<1 / 3$ of lobules & $\geqq 1 / 3$ of lobules \\
& & &
\end{tabular}

\section{（1）ヨーロッパ分類による予測}

CR群はCPH $3 / 12$ 例 $(25 \%) \cdot \mathrm{CAH} 2 \mathrm{~A} 8 / 12$

例 $(67 \%)$, NCR群はそれぞれ $5 / 14$ 例 (36\%)

- $8 / 14$ 例 $(57 \%)$ と, いずれの群も CAH2A が 高率にみられたが, 両群間で $\mathrm{CPH}$ ・CAH $2 \mathrm{~A} ・ 2 \mathrm{~B}$
のいずれの組織型も有意差はなかった（表- 5 ）.

(2) Modified HAI スコアによる予測

壊死炎症反応・線維化, および Total のいずれ においてもスコアが高くなるにつれて NCR 群の 方がCR群と比較して高率にみられた．壊死炎症 
表 - 4 IFN治療効果別の臨床所見 (IFN療法前)の比較

\begin{tabular}{|c|c|c|c|c|}
\hline & $\mathrm{CR}(\mathrm{n}=12)$ & $\operatorname{NCR}(n=14)$ & $\mathrm{p}$ & value \\
\hline 1. IFN開始時年齢(歳) & $8.9 \pm 3.0^{*}$ & $10.5 \pm 4.7^{*}$ & & 30 \\
\hline 2. 推定感染期間 (年) & $3.8 \pm 1.7^{*}$ & $4.4 \pm 2.0^{*}$ & & 43 \\
\hline 3. 性別 : 女児 & $4(33 \%)$ & $4 \quad(29 \%)$ & & .79 \\
\hline 4. 基礎疾患：A群 & $6(50 \%)$ & $13(93 \%)$ & & .05 \\
\hline $\begin{array}{l}\text { 5. HCV genotypea } \\
\text { : II型 (含混合感染) }\end{array}$ & $6(55 \%)$ & $12(92 \%)$ & & .05 \\
\hline $\begin{array}{l}\text { 6. 血清HCV-RNA量b } \\
\left(\log _{10} \quad コ ヒ ゚ ー / m l\right)\end{array}$ & $6.3 \pm 2.1$ & $7.7 \pm 1.3^{*}$ & & .05 \\
\hline 7. 血清ALT (IU/L) & $103.2 \pm 45.1^{*}$ & $55.7 \pm 33.6^{*}$ & & .01 \\
\hline
\end{tabular}

表 - 5 IFN治療効果別の組織像 (ヨーロッパ分類, IFN療法前) の比較

\begin{tabular}{|c|c|c|c|c|}
\hline & $\mathrm{CR}(\mathrm{n}=12)$ & $\operatorname{NCR}(n=14)$ & $\mathrm{p}$ & value \\
\hline $\mathrm{CPH}$ & $3(25 \%)$ & $5(36 \%)$ & & .56 \\
\hline CAH2A & $8(67 \%)$ & $8(57 \%)$ & & .62 \\
\hline САН2B & $1(8 \%)$ & $1(7 \%)$ & & .91 \\
\hline
\end{tabular}

C P H : chronic persistent hepatitis CAH2A : chronic aggressive hepatitis (moderate) CAH2B : chronic aggressive hepatitis (severe)

反応スコア 6 または 7 は NCR 群が $4 / 14$ 例 (29\%)・CR群が0/12例 $(0 \%)$ と NCR 群が有意 に高率 $(\mathrm{p}=0.044)$ であったが, その他のスコア では両群間に有意差はなかった（表-6)。また， 各スコアの平均值はCR 群 vs. NCR 群でそれぞれ $4.0 \pm 2.1$ vs. $5.2 \pm 3.1 \cdot 1.2 \pm 0.6$ vs. $1.3 \pm 0.6 \cdot$ $5.3 \pm 2.7$ vs. $6.5 \pm 3.7$ で有意差がなかった $(\mathrm{p}=$ $0.27 \cdot 0.88 \cdot 0.34)$.

(3) 胆管障害・リンパろ胞形成・好酸体壊死・ 脂肪変性，および鉄沈着の 5 項目の組織所見によ る予測

胆管障害・好酸体壊死，および脂肪変性は $\mathrm{CR}$ 群 vs. NCR群でそれぞれ $4 / 12$ 例 $(33 \%)$ vs. $9 / 14$ 例 $(64 \%) \cdot 1 / 12$ 例 $(8 \%)$ vs. $2 / 14$ 例
$(14 \%) \cdot 1 / 12$ 例 $(8 \%)$ vs. $4 / 14$ 例 $(29 \%)$ と いずれの組織所見ともNCR群に多かったが有意 差がなかった (表-7).リンパろ胞形成は， CR 群で $5 / 12$ 例 $(42 \%) \cdot \mathrm{NCR}$ 群で $3 / 14$ 例 $(21 \%)$ とCR群に多かったが有意差がなかった（表-7). 一方，鉄沈着は CR群で $1 / 12$ 例 $(8 \%) \cdot \mathrm{NCR}$ 群で $8 / 14$ 例 $(57 \%)$ と NCR 群に有意に多かっ た $(\mathrm{p}=0.009)($ 表 -7$)$.また, 鉄沈着例（計 9 例）はいずれもA群に属していたＡ群において， CR 群と NCR 群との間で鉄沈着の有所見例を比 較すると，それぞれ $1 / 6$ 例 $(17 \%) \cdot 8 / 13$ 例 $(62 \%)$ と NCR 群に多い傾向 $(\mathrm{p}=0.068)$ があっ た.

5 項目の組織所見の保有項目数ごとの症例数を CR 群と NCR 群との間で比較すると, 複数 ( 2 項 目以上）の組織所見を有する症例は $\mathrm{CR}$ 群で $4 /$ 12例 $(33 \%) \cdot \mathrm{NCR}$ 群で10/14例 $(71 \%)$ と NCR 群に多い傾向にあった (表-8). とくに，5項目 中いずれか 3 項目以上を有する症例はCR群で0/ 12例 $(0 \%) \cdot \mathrm{NCR}$ 群で $5 / 14$ 例 $(36 \%)$ と NCR 群に有意に多く $(\mathrm{p}=0.021), 5$ 項目の組織所見 のうち唯一 CR群に高率にみられたリンパろ胞形 成を除いた 4 項目中いずれか 2 項目以上を有する 症例も, CR群で $1 / 12$ 例 $(8 \%) \cdot \mathrm{NCR}$ 群で10／ 14 例 $(71 \%)$ と NCR 群に有意に多かった（p= 0.001）（表-8）. 
表 - 6 IFN治療効果別のModified HAIスコアの (IFN療法前)の比較

(1) 壊死炎症反応スコア

\begin{tabular}{|c|c|c|c|c|}
\hline スコア & $\mathrm{CR}(\mathrm{n}=12)$ & $\operatorname{NCR}(\mathrm{n}=14)$ & $\mathrm{p}$ & value \\
\hline $2 \sim 3$ & $6 \quad(50 \%)$ & $4 \quad(29 \%)$ & & .26 \\
\hline $4 \sim 5$ & $5 \quad(42 \%)$ & $5 \quad(35 \%)$ & & .76 \\
\hline $6 \sim 7$ & $0(0 \%)$ & $4 \quad(29 \%)$ & $<$ & .05 \\
\hline $8 \leqq$ & $1(8 \%)$ & $1(7 \%)$ & & .91 \\
\hline
\end{tabular}

\begin{tabular}{lrrrr}
\hline \multicolumn{2}{l}{ (2) 線維化スコア } \\
\hline スコア & $\mathrm{CR}(\mathrm{n}=12)$ & $\mathrm{NCR}(\mathrm{n}=14)$ & $\mathrm{p}$ & value \\
\hline 1 & $10(84 \%)$ & $11(79 \%)$ & .76 \\
2 & $1(8 \%)$ & $2(14 \%)$ & .64 \\
3 & $1(8 \%)$ & $1(7 \%)$ & .91 \\
4 & $0(0 \%)$ & $0(0 \%)$ & - \\
\hline
\end{tabular}

( 3 ) Totalスコア

\begin{tabular}{|c|c|c|c|c|}
\hline スコア & $\mathrm{CR}(\mathrm{n}=12)$ & $\operatorname{NCR}(\mathrm{n}=14)$ & $\mathrm{p}$ & value \\
\hline $3 \sim 4$ & $6 \quad(50 \%)$ & $4 \quad(29 \%)$ & & 24 \\
\hline $5 \sim 6$ & $4 \quad(34 \%)$ & $5 \quad(35 \%)$ & & 61 \\
\hline $7 \sim 8$ & $1(8 \%)$ & $2(14 \%)$ & & .56 \\
\hline $9 \sim 10$ & $0 \quad(0 \%)$ & $2(14 \%)$ & & .28 \\
\hline $11 \leqq$ & $1 \quad(8 \%)$ & $1(7 \%)$ & & .72 \\
\hline
\end{tabular}

\section{IFN 療法前後での肝生検所見の比較}

IFN 療法の終了後 2 年を経過した時点で肝生検 を実施し得た 9 例中 7 例は CR 例で, 残りの 2 例 はNCR例であった（図-1,-2,-3). Modified HAI スコアのうち，壊死炎症反応スコアはCR例 では全例, NCR例では 1 例の計 8 例がスコア 2 まで改善したが (図-1,-2), 残りの 1 例はス コア7から8へわずかに増悪していた（図-3）. 線維化スコアは CR例では 4 例・NCR例では 1 例 の計 5 例のみでしか改善せず, 残りの 4 例 ( CR 3 例・NCR 1 例) では不変と, 壊死炎症反応スコ アに比べ改善例が少なかった（図-1). Total ス コアの変化は壊死炎症反応スコアと同様に, 改善 8 例 (CR 7 例 ・ NCR 1 例), 軽度の増悪 1 例で あったがスコア0,すなわち正常化例はなく, Minimal change（3 例）あるいはヨーロッパ分類 上の $\mathrm{CPH}$ （5 例）であった（図-1）. 鉄沈着は IFN 療法前に 9 例中 2 例 (CR 1 例 ・ NCR 1 例) にみられ，いずれも IFN療法後も残存していた.
表 - 7 IFN治療効果別の組織所見 (IFN療法前) の比較 (1) 胆管障害

\begin{tabular}{|c|c|c|c|c|}
\hline grade & $\mathrm{CR}(\mathrm{n}=12)$ & $\operatorname{NCR}(\mathrm{n}=14)$ & $\mathrm{p}$ & value \\
\hline 1 & $3(25 \%)$ & $6(43 \%)$ & & .34 \\
\hline 2 & $1(8 \%)$ & $3(21 \%)$ & & .37 \\
\hline 有所見例 & $4 \quad(33 \%)$ & $9 \quad(64 \%)$ & & .12 \\
\hline
\end{tabular}

(2) リンパろ胞形成

\begin{tabular}{|c|c|c|c|c|}
\hline grade & $\mathrm{CR}(\mathrm{n}=12)$ & $\operatorname{NCR}(\mathrm{n}=14)$ & $\mathrm{p}$ & value \\
\hline 1 & $(17 \%)$ & $(14 \%)$ & & .87 \\
\hline 2 & $3(25 \%)$ & $1(7 \%)$ & & .21 \\
\hline 有所見例 & $5 \quad(42 \%)$ & $3(21 \%)$ & & 27 \\
\hline
\end{tabular}

(3) 好酸体壊死

\begin{tabular}{|c|c|c|c|c|}
\hline grade & $\mathrm{CR}(\mathrm{n}=12)$ & $\operatorname{NCR}(n=14)$ & $p$ & value \\
\hline 1 & $1(8 \%)$ & $2 \quad(14 \%)$ & & 64 \\
\hline 2 & $0 \quad(0 \%)$ & $0 \quad(0 \%)$ & & - \\
\hline 有所見例 & $1(8 \%)$ & $2(14 \%)$ & & .64 \\
\hline
\end{tabular}

(4) 脂肪変性

\begin{tabular}{|c|c|c|c|c|}
\hline grade & $\mathrm{CR}(\mathrm{n}=12)$ & $\operatorname{NCR}(n=14)$ & $\mathrm{p}$ & value \\
\hline 1 & $0(0 \%)$ & $1(7 \%)$ & & .35 \\
\hline 2 & $1(8 \%)$ & $3(21 \%)$ & & .36 \\
\hline 有所見例 & $1(8 \%)$ & $4 \quad(28 \%)$ & & .19 \\
\hline
\end{tabular}

( 5 ) 鉄沈着

\begin{tabular}{|c|c|c|c|}
\hline grade & $\mathrm{CR}(\mathrm{n}=12)$ & $\operatorname{NCR}(\mathrm{n}=14)$ & value \\
\hline 1 & $0(0 \%)$ & $4(29 \%)$ & $<.05$ \\
\hline 2 & $1(8 \%)$ & $4 \quad(29 \%)$ & .19 \\
\hline 有所見例 & $1(8 \%)$ & $8 \quad(58 \%)$ & $<.01$ \\
\hline
\end{tabular}

表 - 8 IFN治療効果別にみた組織所見*の 保有項目数(IFN療法前)の比較

\begin{tabular}{|c|c|c|c|}
\hline 保有項目数 & $\mathrm{CR}(\mathrm{n}=12)$ & $\operatorname{NCR}(n=14)$ & value \\
\hline 0 & $4(33 \%)$ & $4 \quad(29 \%)$ & .79 \\
\hline 1 & $4 \quad(33 \%)$ & $0 \quad(0 \%)$ & $<.05$ \\
\hline 2 & $4 \quad(33 \%)$ & $5 \quad(36 \%)$ & .90 \\
\hline 3 & $0 \quad(0 \%)$ & $4 \quad(29 \%)$ & $<.05$ \\
\hline 4 & $0 \quad(0 \%)$ & $1(7 \%)$ & .35 \\
\hline 5 & $0 \quad(0 \%)$ & $0 \quad(0 \%)$ & - \\
\hline $2 \leqq$ & $4(33 \%)$ & $10(71 \%)$ & .05 \\
\hline $3 \leqq$ & $0 \quad(0 \%)$ & $5(36 \%)$ & $<.05$ \\
\hline $2 \leqq * *$ & $1(8 \%)$ & $10(71 \%)$ & $<.01$ \\
\hline
\end{tabular}

*胆管障害・リンパろ胞形成・好酸体壊死・脂肪変性および

鉄沈着の 5 項目

**リンパろ胞形成を除いた 4 項目での保有項目数 

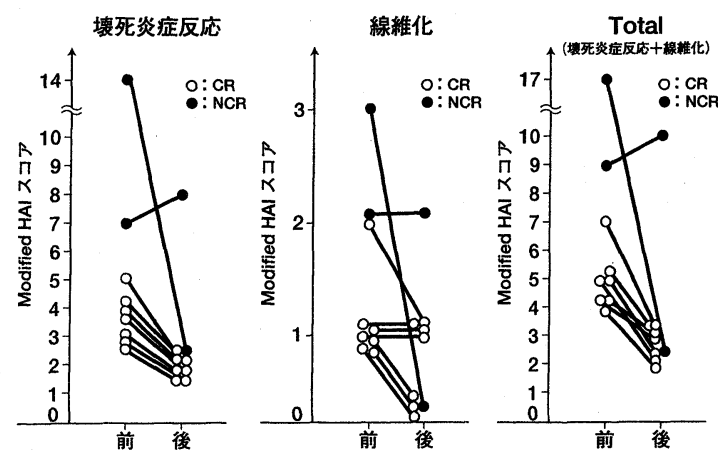

図－1 IFN治療前後での Modified HAI スコアの変化

\section{考察}

\section{1．臨床所見によるIFN治療効果の予測}

今回の検討より,C型慢性肝炎に対するIFN 療 法により治癒を期待できる症例（著効例）は46\% であった．従来の小児例での報告17)～19）と比べ IFNの投与方法あるいは対象の例数や基礎疾患に 相違はあるが, IFN 治療効果は同様であり，成人 例 $(20 \sim 30 \%)^{3) \sim 10)}$ に比し高率であった。この 差は，小児例は感染期間が短いため HCV の変異 が少ないこと, 免疫能が成人とは若干異なってい ることが推測されているが17) 20)，十分に解明さ れていない.

IFN 療法は高額であるにもかかわらず，効果の 不十分な症例も多数存在する3) ${ }^{4)}$. そこで, IFN のより適切な適応基準を設定する目的でIFN療法 の効果予測因子が検討されている. 本検討では, CR群はNCR群と比較してHCV genotypeの II 型 が有意に少なく，また血清 HCV-RNA 量が有意 に低值であった.このように, 小児例ではこの 2 因 子はIFN療法のウイルス学的な効果予測因子とし て重要であった。成人例でも HCV の genotype (II 型以外) $\left.{ }^{8)} \sim 10\right)$ および低ウイルス量 ${ }^{8)}$ 10) が IFN 著効の条件としてほほ確実となっている.

筆者の検討では治療前の血清 ALT 值が CR 群 で有意に高值であり, 宿主側の効果子測因子とし て重要であった，成人例では性 ${ }^{29)}$ ・感染期間 9)・
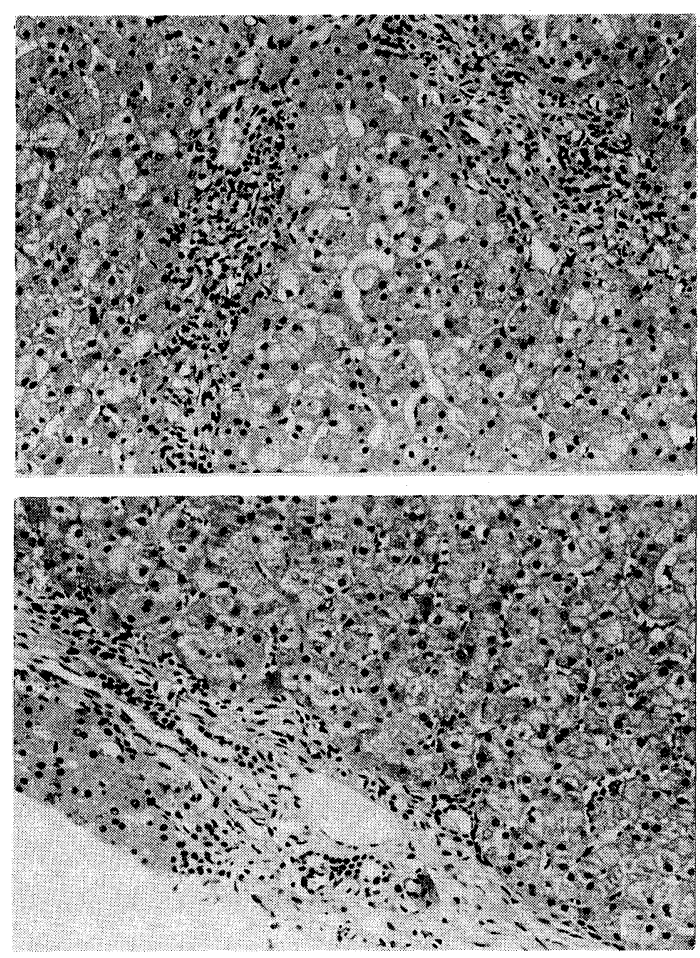

图 - 2 CR 例（患児 K.M. 12歳 女児 推定感染 期間 3 年) の IFN療法前後での肝生検標本 (H. E. 染色)

治療前 (写真上)：門脈域は線維增生を伴った軽度から 中等度の細胞浸潤により拡大し, 削り取り壊死も軽度か ら中等度にみられる.小葉内には線維がわずかに侵入し, 肝細胞は軽度に腫大している。

(壊死炎症反応 $5 *$, 線維化 $2 *$ )

治療後 (写真下)：門脈域は軽度の線維增生と細胞浸潤 を, 小葉内は軽度の肝細胞の腫大を残存している.

(壞死炎症反応 $2 *$, 線維化 $1^{*}$ )

*Modified HAI スコア

治療前の血清トランスアミナーゼ值7) などが報告 されている，また，基礎疾患別にIFN治療効果を 比較すると，A群には NCR例が，B群には CR例 がそれぞれ有意に多かったＡ群では基礎疾患自 体, 抗癌剂などの免疫抑制剂, および複数のドナ 一からの頻回輸血により, 旺盛な HCV の増殖や $\mathrm{HCV}$ 以外の要因による肝障害をきたしていた可 

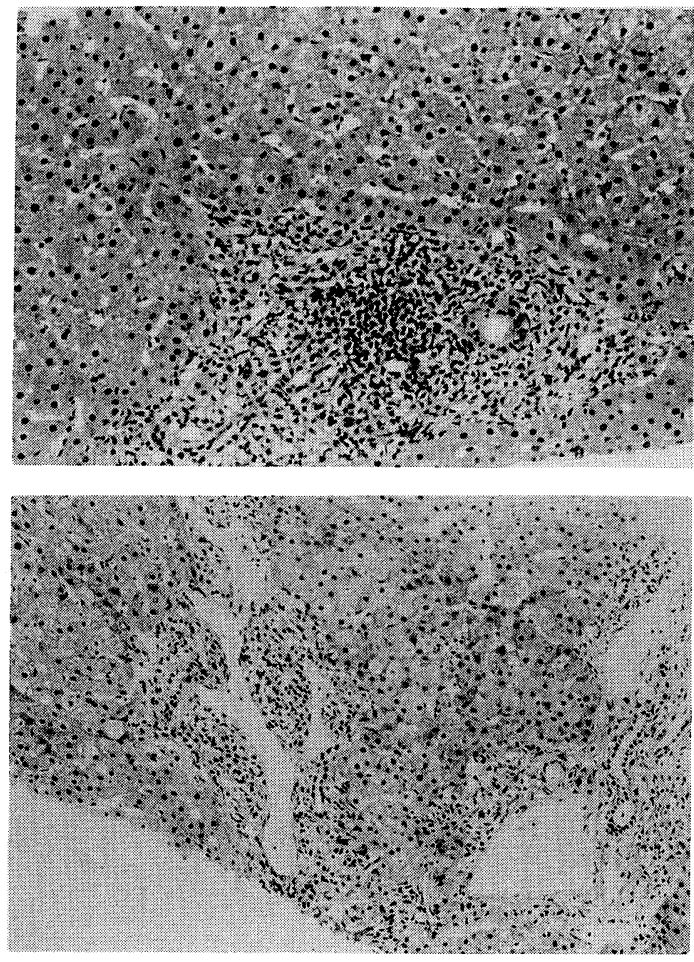

図 - 3 NCR例（患児H.Y. 12歳 男児 推定感染 期間 3 年）の IFN療法前後での肝生検標本 (H. E. 染色)

治療前 (写真上)：門脈域は線維増生を伴った著明な細 胞浸潤により拡大し, 削り取り壊死は軽度から中等度に みられる。葉内には線維がわずかに侵入し，肝細胞は 軽度に腫大している。

(壊死炎症反応 $7 *$, 線維化 $2 *$ )

治療後 (写真下)：門脈域の著明な細胞浸潤, 中等度の 削り取り壊死, 小葉内へのわずかな線維の侵入および肝 細胞の軽度の腫大がみられる。

(壊死炎症反応 $8 *$, 線維化 $2 *$ )

*Modified HAI スコア

能性がある14）15).これらの影響が基礎疾患の治 療終了後どの程度持続するかは不明である15).

以上より，小児の C 型慢性肝炎に対する IFN 治療効果の臨床上の予測因子としてHCVの genotype とウイルス量・血清ALT值，および基礎疾 患が重要と考えられるが，この 4 因子は互いに関
連している可能性が高く, 今後は症例数を増やし て多変量解析を行い検討する必要がある.

2. 病理組織所見によるIFN治療効果の予测

（1）ヨーロッパ分類による予測

本検討では，CR 群と NCR 群との間で $\mathrm{CPH}$ ・ $\mathrm{CAH} 2 \mathrm{~A}$ ，およびCAH2Bの各組織別のIFN 治療 効果に有意差はなかった. Martinot-Peignoux ら9) は成人の C 型慢性肝炎144例を $\mathrm{CPH} \cdot \mathrm{CAH}$, および CAH with cirrhosisに分けてIFN治療効 果を比較したが，各組織型別に有意差がなかった としている. 一方, $\mathrm{CPH}$ の IFN 効果は $\mathrm{CAH} 2 \mathrm{~A}$ や CAH2B と比較して良好であるとの報告10）も ある.このようにヨーロッパ分類によるIFN効果 の予測に関して一定の見解はなく，小児例でもヨ 一ロッパ分類での効果予測は困難であった. しか し, CR群ではCPHよりむしろCAH2A が多かっ たこと, IFN 治療前の血清 ALT 值は CR 群に有 意に高率であったことから，著効を得るためには ある程度の炎症反応が必要と考えられた。

(2) Modified HAIスコアによる予測

Total ・壊死炎症反応, および線維化のいずれ のスコアとも CR 群と NCR 群との間で有意差はな く, 各段階のスコアの症例数を両群間で比較して も壊死炎症反応スコアが 6 または 7 以外では有意 差はなかった.したがって, 小児例では IFN 療法の 効果予測にModified HAIスコアは有用ではなか った. 成人例では壊死炎症反応よりも線維化が IFN 療法の効果に差をもたらすとの報告6）29）30) が多い. その原因として線維化の進展に伴う小葉 構築の歪みによってIFNの薬理動態が変化するこ とが推測されている30). 小児例では, HAIの Total スコアを IFN 著効 6 例と非著効 8 例とで比 較し有意差がなかったとの報告19）がある．小児 の C型慢性肝炎例は成人例と比較して組織進展度 が軽く16)，本検討でも，線維化スコアが 2 末満の 症例は $24 / 26$ 例 $(92 \%)$ と高率であり, IFN治療 効果別の線維化スコアに差が現れなかったと考え られた。

（3）5 項目の組織所見による予測

成人の C 型慢性肝炎に特徴的な病理組織所見と 
して, 胆管障害・リンパろ胞形成・好酸体壊死, および脂肪変性などがある5（31）32．これら 4 項目 のうちリンパろ胞形成は $\mathrm{CR}$ 群に, その他の 3 項 目はNCR群に高率にみられたが両群間で有意差 がなく，4 項目のいずれとも単独ではIFN療法の 効果予測因子として重要ではなかった.リンパろ 胞形成は HCV 感染肝細胞に対するリンパ球によ る免疫反応を示唆する所見であり ${ }^{33)}$, IFNは抗ウ イルス作用のほかに宿主の免疫賦活作用も有して いる ${ }^{34)}$. したがって，リンパろ胞形成例では IFN 投与により肝障害が増悪し，リンパろ胞形成は IFN抵抗性を示唆すると予想された。しかし，今 回の検討ではリンパろ胞形成 8 例中 5 例は IFN 著効例であり，IFN の効果を得るには宿主に $\mathrm{HCV}$ 排除機構としての免疫反応が，ある程度は 必要であることが示唆された。

最近, 肝組織中の鉄沈着や鉄含有量が IFN療 法の効果を規定する因子として注目されている18) 35) 37). 筆者の検討では鉄沈着の有所見例は NCR 群に有意に多かった. Clemente ら ${ }^{18)}$ も基礎疾患 にサラセミアがあり, IFN 療法を行った小坚のC 型慢性肝炎51例についての検討で，肝組織中の鉄 沈着の程度と鉄含有量は正の相関を示し，鉄沈着 の程度が少ない例に IFN の responder が多いと し，成人例でも同様の報告 ${ }^{35)}$ ３7) がある. した がって, IFN療法の効果予測に肝組織中の鉄沈着 は重要な因子と考えた。鉄沈着例は全例とも頻回 の輸血歴を有するA群に属しており，この鉄沈着 は，輸血によると考えられた.

また，胆管障害・リンパろ胞形成・好酸体壊 死・脂肪変性, および鉄沈着の 5 項目について対 象例ごとの保有項目数を CR 群と NCR群との間で 比較すると，いずれか 3 項目以上を有する例は NCR群のみであり，リンパろ胞形成を除いた 4 項目中いずれか 2 項目以上を有する例はNCR群 に有意に多かった。したがって，5 項目の組織所 見の保有項目数もIFNの効果予測因子として考慮 する必要がある。

\section{IFN療法の病理組織学的な子後}

IFN 療法のウイルス学的および肝機能的な著効
例では組織学的にも壊死炎症や線維化は改善する ことが知られている3４４17）19)。今回，IFN治療前 と治療終了後 2 年を経過した時点での肝生検所見 を比較し得た 9 例のうちCRは 7 例, NCR は 2 例 であった，CR例では壊死炎症反応は全例で，線 維化は 4 例でのみ改善していたが，正常化例はな くCPHあるいはMinimal changeであった．成人 例でもIFN療法の終了後 1 ～ 2 年を経過した時点 では，肝の実質炎や削り取り壊死は消失するが門 脈域の炎症細胞浸潤や線維化が残存し正常化例は 少ないという38) 39)。したがって，IFN 著効例での 病理組織学的な治癒判定にはIFN療法の終了後 2 年以上の経過を要すると考えられた。一方, NCR 2 例のうち 1 例では壊死炎症反応スコアがわずか に増悪していた。これは, IFN療法の直後には改 善しその後に増悪したのか, あるいは緩徐に増悪 したのか，不明である．今後も肝生検を含めた慎 重な経過観察が必要である.

\section{結 論}

1. 小児のC型慢性肝炎に対するIFN療法の効果 子測因子として,

(1) 臨床的には，ウイルス側の因子として HCV genotype，および治療前の血清 HCV-RNA 量 が，宿主側の因子として基礎疾患および治療前の 血清ALT值が重要であった.

(2) 病理組織学的には鉄沈着ならびに 5 項目の 組織所見の保有項目数が重要であった。しかし， ヨーロッパ分類や肝組織進行度の半定量的評価法 ではIFN療法の効果予測は困難であった。

2. IFN療法を終了後， 2 年の経過で肝生検所見 （とくに壊死炎症反応）は改善していたが正常化 例はなく, 逆に増悪傾向を示す例 (非著効例) も あり，肝生検を含めた経過観察が必要と考えた。

稿を終えるにあたり，ご指導・ご校閲を賜りました病 理学第一講座の須田耕一教授に深謝致します。また，直 接ご指導をいただきました防衛医科大学小児科の藤澤知 雄講師に謝意を表するとともに, 病理組織学的検索に多 
大のご指導をいただいた乾 道夫客員教授，ウイルス学 的検索をしていただいた防衛医科大学小児科の乾あやの 博士にお礼申し上げます。

なお本稿の要旨は，第22回日本小児栄養消化器病学会 (1995年10月 京都), 第99回日本小児科学会学術集会 （1996年 4 月 熊本）および第85回日本病理学会総会 （1996年 4 月 東京）にて発表した.

\section{参考文献}

1) Kiyosawa K, Sodeyama T, Tanaka E, et al. : Interrelationship of blood transfusion, non-A, non-B hepatitis and hepatocellular carcinoma : Analysis by detection of antibody to hepatitis C virus. Hepatology, $1990 ; 12: 671 \sim 675$.

2) Takahashi M, Yamada G, Miyamoto R, et al. : Natural course of chronic hepatitis C. Am J Gastroenterol., $1993 ; 88: 240 \sim 243$.

3) Davis GL, Balart LA, Schiff ER, et al. : Treatment of chronic hepatitis $\mathrm{C}$ with recombinant interferon alpha: A multicenter randomized, controlled trial. N Engl J Med., 1989 ; 321 : 1501 1506.

4) Di Bisceglie AM, Martin P, Kassianides C, et al. : Recombinant interferon alfa therapy for chronic hepatitis C ; A randomized, doubleblind, placebo-controlled trial. N Engl J Med., 1989 ; $321:$ 1506 1510.

5) Lefkowitch JH, Schiff ER, Davis GL, et al. : Pathological diagnosis of chronic hepatitis $\mathrm{C}$ : A multicenter comparative study with hepatitis B. Gastroenterology, $1993 ; 104: 595 \sim 603$.

6) Uchida $T$, Taira M, Shikata $T$, et al. : Histological difference between complete responders and non-responders to interferon therapy of the livers of patients with chronic hepatitis $C$. Acta Pathol Jpn., $1993 ; 43: 230 \sim 236$.

7) Serfaty L, Giral P, Loria A, et al. : Factors predictive of the response to interferon in patients with chronic hepatitis C. J Hepatol.,
$1994 ; 21: 12 \sim 17$.

8) Matsumoto A, Tanaka E, Suzuki T, et al.: Viral and host factors that contribute to efficacy of interferon- $\alpha_{2 a}$ therapy in patients with chronic hepatitis C. Dig Dis Sci., 1994 ; 39: 1273 1280.

9) Martinot-Peignoux M, Marcellin P, Pouteau $\mathrm{M}$, et al. : Pretreatment serum hepatitis $\mathrm{C}$ virus $\mathrm{RNA}$ levels and hepatitis $\mathrm{C}$ virus genotype are the main and independent prognostic factors of sustained response to interferon alfa therapy in chronic hepatitis C. Hepatology, $1995 ; 22: 1050 \sim 1056$.

10) Ishibashi K, Kashiwagi T, Tanaka $Y$, et al. : Predictive factors for efficacy of interferon therapy in chronic hepatitis type C. HepatoGastroenterol., 1995 ; 42 : 535 541.

11）尾上昌弘, 乾あやの, 大川貴司, 他：小児C型 慢性肝炎の臨床 - 病理学的検討一一基礎疾患別 の自然経過を中心として. 日児誌, $1996 ; 100$ ： $31 \sim 38$.

12) Bortolotti F, Jara P, Diaz C, et al. : Posttransfusion and community-acquired hepatitis $\mathrm{C}$ in childhood. J Pediatr Gastroenterol Nutr., 1994 ; $18: 279 \sim 283$.

13）藤沢知雄, 白木和夫：小児のC型慢性肝炎に関 する多施設合同調查一一長期追跡例の臨床的検 討. 日児誌, $1994 ; 98 ： 806$.

14) Inui $A$, Fujisawa $T$, Miyagawa $Y$, et al. : Histologic activity of the liver in children with transfusion-associated chronic hepatitis C. J Hepatol., 1994； $21 ： 748 \sim 753$.

15）乾あやの：小児におけるC型慢性肝炎の病理組 織学的検討一B型慢性肝炎との比較検討を含め て. 順天堂医学, $1995 ; 41 ： 338 \sim 348$.

16）鹿毛政義：慢性 $B$ 型・C型肝炎の病理一成人 との比較. 小児内科, $1995 ; 27: 497 \sim 501$.

17) Ruiz-Moreno M, Rua MJ, Castillo I, et al. : Treatment of children with chronic hepatitis $\mathrm{C}$ with recombinant interferon- $\alpha$; A pilot 
study. Hepatology, $1992 ; 16: 882 \sim 885$.

18) Clemente MG, Congia M, Lai ME, et al. : Effect of iron overload on the response to recombinant interferon-alfa treatment in transfusion-dependent patients with thalassemia major and chronic hepatitis C. J Pediatr., $1994 ; 125: 123 \sim 128$.

19) Bortolotti F, Giacchino R, Vajro $P$, et al. : Recombinant interferon-alfa therapy in chiIdren with chronic hepatitis C. Hepatology, $1995 ; 22: 1623 \sim 1627$.

20) Fujisawa $T$, Inui $A$, Ohkawa $T$, et al. : Response to interferon therapy in children with chronic hepatitis C. J Pediatr., 1995 ; 127 : $660 \sim 662$.

21) Komatsu K, Fujisawa $T$, Inui $A$, et al. : Efficacy of interferon in treating chronic hepatitis $\mathrm{C}$ in children with a history of acute leukemia. Blood, $1996 ; 87: 4072 \sim 4075$.

22) Iorio R, Pensati P, Porzio S, et al. : Lymphoblastoid interferon alfa treatment in chronic hepatitis C. Arch Dis Child., 1996 ;

74: 152 156.

23) International Group: Acute and chronic hepatitis revisited. Lancet, 1977 ; ii : 914 919.

24) Schvarcz R, Glaumann H, Weiland O, et al. : Histological outcome in interferon alpha$2 \mathrm{~b}$ treated patients with chronic posttransfusion non-A, non-B hepatitis. Liver, 1991 ; $11: 30 \sim 38$.

25) Knodell RG, Ishak KG, Black WC, et al. : Formulation and application of a numerical scoring system for assessing histological activity in asymptomatic chronic active hepatitis. Hepatology, $1981 ; 1: 431 \sim 435$.

26) Okamoto H, Sugiyama $Y$, Okada $S$, et al. : Typing hepatitis $C$ virus by polymerase chain reaction with type-specific primers: Application to clinical surveys and tracing infec- tious sources. J Gen Virol., $1992 ; 73: 673 \sim 679$.

27) Okamoto H, Okada S, Sugiyama $Y$, et al. : Detection of hepatitis $C$ virus RNA by a twostage polymerase chain reaction with two pairs of primers deduced from the $5^{\prime}$ noncoding region. Jpn J Exp Med., 1990 ; 60 : $215 \sim 222$.

28) Ishiyama N, Katayama K, Ishimi N, et al. : Quantitative detection of hepatitis $\mathrm{C}$ virus RNA by multicyclic RT-PCR. Int Hepatol Commun ., $1993 ; 1: 72 \sim 79$.

29) Causse $X$, Godinot $H$, Chevallier $M$, et al. : Comparison of 1 or $3 \mathrm{MU}$ of interferon alfa $-2 \mathrm{~b}$ and placebo in patients with chronic non-A, non-B hepatitis. Gastroenterology, 1991 ; 101: 497 502.

30) Tsubota A, Chayama K, Ikeda K, et al.: Factors predictive of response to interferon- $\alpha$ therapy in hepatitis $\mathrm{C}$ virus infection. Hepatology, $1994 ; 19: 1088 \sim 1094$.

31) Scheuer PJ, Ashrafzadeh P, Sherlock S, et al. : The pathology of hepatitis C. Hepatology, $1992 ; 15: 567 \sim 571$.

32) Bach N, Thung SN, Schaffner F : The histological features of chronic hepatitis $\mathrm{C}$ and autoimmune chronic hepatitis; A comparative analysis. Hepatology, $1992 ; 15: 572 \sim 577$.

33) Gerber MA : Pathobiologic effects of hepatitis C. J Hepatol., 1995 ; 22 (Suppl 1) : 83 86.

34) Jonas $\mathrm{MM}:$ Interferon- $\alpha$ for viral hepatitis. J Pediatr Gastroenterol Nutr., 1996 ; 23 : 93 $\sim 106$.

35) Van Thiel DH, Friedlander L, Fagiuoli S, et al. : Response to interferon $\alpha$ therapy is influenced by the iron content of the liver. J Hepatol., $1994 ; 20$ : 410 415.

36) Barton AL, Banner BF, Cable EE, et al.: Distribution of iron in the liver predicts the response of chronic hepatitis $\mathrm{C}$ infection to interferon therapy. Am J Clin Pathol., 1995 ; 
$103: 419 \sim 424$.

37) Olynyk JK, Rajender Reddy K, Di Bisceglie et al.: Hepatic iron concentration as a predictor of response to interferon alfa therapy in chronic hepatitis C. Gastroenterology, 1995 ; 108 : 1104 1109.

38) Shindo M, Arai K, Sokawa $Y$, et al. : Hepatic hepatitis $\mathrm{C}$ virus RNA as a predictor of a long-term response to interferon- $\alpha$ therapy. Ann Intern Med., 1995 ; 122 : 586 591.

39) Reichard O, Glaumann H, Fryden A, et al. : Two-year biochemical, virological, and histological follow-up in patients with chronic hepatitis $\mathrm{C}$ responding in a sustained fashion to interferon alfa-2b treatment. Hepatology, $1995 ; 21$ : 918 922.

\section{Original Paper}

\section{Summary}

\section{A clinicopathological study of efficacy of interferon therapy in children with chronic hepatitis $\mathrm{C}$}

Objective : To identify predictors influencing the response to interferon (IFN) therapy in children with chronic hepatitis $\mathrm{C}(\mathrm{CH}-\mathrm{C})$ and to assess histological findings of the liver long after IFN therapy.

Patients and Methods: Twenty-six children with $\mathrm{CH}-\mathrm{C}$ who received natural IFN alfa therapy for 6 months (total dose : $8 \mathrm{MU} / \mathrm{kg}$ ), were divided into two groups : 12 patients showing a complete response $(\mathrm{CR})$ and 14 patients with a partial response (PR). "CR" was defined as normalization of serum alanine aminotransferase (sALT) and the disappearance of hepatitis $\mathrm{C}$ virus ribonucleic acid (HCV RNA) from serum within 6 months after the cessation of therapy and continuing for at least 6 months thereafter. "PR" was defined as any other pattern of $\mathrm{s}-\mathrm{ALT}$ and serum HCV RNA.

Liver biopsies were performed within 6 months before IFN therapy in all 26 children, and again 2 years after therapy in 9 of the children. Liver histology was categorized according to the standard criteria and Knodell's index of histological activity with some modifications (Modified HAI). Moreover, the frequency of five histological features (bile duct damage, lymphoid follicles and/or aggregates, acidophil bodies, steatosis and iron deposition) were examined.

Results: There were no significant differences on conventional histological diagnosis or in modified HAI for total, necroinflammation and fibrosis between the CR group and the PR group. Bile duct damage, acidophil bodies and steatosis were frequently observed in the PR group, while lymphoid follicles and/or aggregates were frequently recognized in the $\mathrm{CR}$ group. However, there were no significant differences in each of the four histological features between the two groups. However, there was 
a significant difference $(\mathrm{p}=0.009)$ in the frequency of liver iron deposition between the CR group ( $8 \%$ ) and the PR group (58\%). Significantly fewer patients in the CR group showed more than three of these five histological features compared to those in the PR group ( $0 \%$ vs $36 \%, p=0.021$ ). There were also significantly fewer children in the CR group showing more than two of these four histological features excluding lymphoid follicles and/or aggregates compared to those in the PR group ( $8 \%$ vs $71 \%$, $\mathrm{p}=0.001$ ). Of the 9 children (CR $: 7$ cases, $P R: 2$ cases) who underwent liver biopsies 2 years after the cessation of IFN therapy, 8 (CR $: 7$ cases, PR $: 1$ case) showed an improved histological diagnosis.

Conclusions: These results suggest that the response to IFN therapy in children with $\mathrm{CH}-\mathrm{C}$ is influenced by hepatic iron deposition and a combination of several histological features. A period of more than 2 years after the cessation of therapy was necessary to determine histological remission in the CR group.

Key words : children, chronic hepatitis C, interferon, liver histology

$$
\text { MASAhiRo ONOUE, M. D. *1) 2) }
$$

*1) Department of Pathology ( I ), Juntendo University School of Medicine, Tokyo, Japan

*2) Department of Pediatrics, Self Defense Forces Central Hospital, Tokyo, Japan 